\title{
PERI-PAROTID LIPOMA, A RARE CASE REPORT
}

\begin{tabular}{|l|lll}
\hline ENT &
\end{tabular}

Dr. Nitish Professor \& Head ENT, Department of ENT- Maharishi Markandeshwar Institute of Baisakhiya Medical Sciences and Research, Mullana, (Distt-Ambala),Haryana, India.

\section{Dr. Saima} Tabassum

Senior Resident, ENT Department of ENT- Maharishi Markandeshwar Institute of Medical Sciences and Research, Mullana,(Distt-Ambala),Haryana, India

\section{Dr. Sajid Iqbal*}

Assistant Professor Surgery, Department of Surgery- Maharishi Markandeshwar Institute of Medical Sciences and Research, Mullana,(Distt-Ambala),Haryana, India.

*Corresponding Author

\section{ABSTRACT}

Lipoma is a common benign tumor affecting the soft tissues arising in every location where fat is normally present. Only $13 \%$ of them arise in the head and neck region and most of these occur subcutaneously in the posterior neck. Rarely, they can develop from deeper planes in the anterior neck, infratemporal fossa, in or around the oral cavity, pharynx, larynx, and parotid gland. They usually present as a benign, slowly growing and rarely recur Clinically, they can be confused with other benign lesions; however, CT and Ultrasonography allows a specific diagnosis to be made in virtually all cases. The aim of this article is to report a unique case of a lipoma with benign microscopic appearance located deep to the subcutaneous tissue in the para-parotid area of a 45 years-old female patient.

\section{KEYWORDS}

\section{Lipoma, Parotid Gland, excision}

\section{INTRODUCTION:}

Lipomas are benign tumors composed of mature white adipocytes and are the most common mesenchymal neoplasms in the adults. Microscopically they are composed of lobules of mature adipocytes, identical to the surrounding adipose tissue except for slight variation in the size and shape of the cells in lipomas [1]. They are relatively common in the upper back, neck, shoulder and abdomen, followed in frequency by proximal portions of the extremities, buttocks and upper thigh, some times lipomas are found in face, hands, lower legs and feet [2]. This neoplasm rarely occurs in the parotid or para-parotid region [3] and according to several authors, lipomas account for less than $4.4 \%$ of the benign parotid gland tumours $[4,5]$. The preferred treatment is surgical excision and recurrence is approximately $5 \%[6]$. Lipomas seem to arise from metaplastic transformation of fibroblasts to lipoblasts [7], but other theories have been proposed [8,9]

\section{CASE REPORT:}

A 45 year old female patient presented to the ENT OPD, MMIMSR, Mullana with a painless swelling on the left side of face of 10 years duration. The swelling was progressively increasing in size since then. Physical examination revealed a mass of the right parotid region which was elastic, soft, mobile, regular, non-tender, non-fluctuant, nonpulsatile and non transilluminant superficial mass.

The overlying skin was found to be normal. There was no other mass palpable in head and neck region. There was no facial Asymmetry. It was associated with deep boring pain in right ear although, rest of the otolaryngological examination was normal.

A high frequency ultrasonography visualized a large well defined hypoechoic lesion measuring $5 \times 2.5 \mathrm{~cm}$ with thin echogenic strands in right parotid gland? Lipoma. No significant cervical lymphadenopathy seen. (Figure 1).

We subjected the patient for $\mathrm{CT}$ scan which revealed low attenuation homogeneous mass with sharp margins on right side with no underlying enchancement. Parotid tissue appeared normal (Figure 2).

We performed tumor excision with facial nerve preservation, under general anesthesia, using a modified Blair's incision. Intraoperatively, a large mass was located in the right parotid region deep to the subcutaneous tissue but superficial to the right parotid gland. The tumor comprised a well circumscribed, soft, yellow, lobulated fatty mass covered with a thin fibrous capsule (Figure 3,4 ). It was easily removed without injury of any major neurovascular structures.

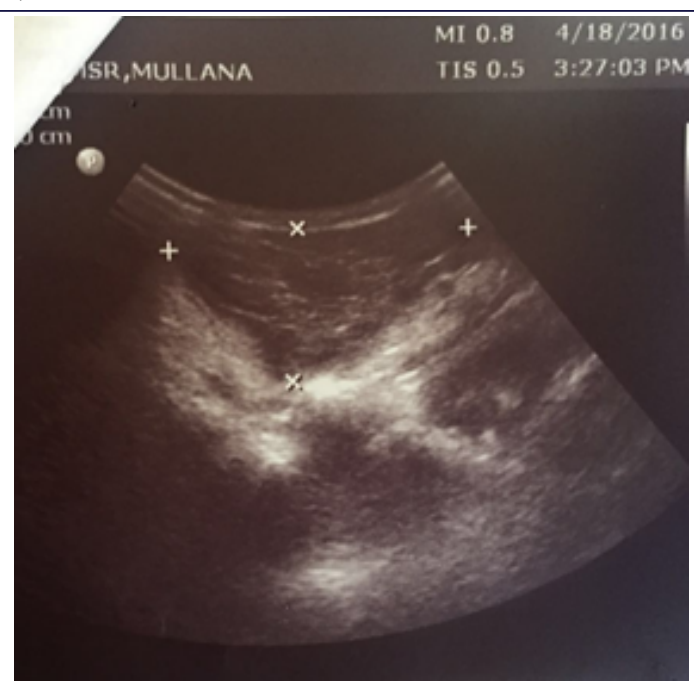

Figure 1: Ultrasonography visualized a large well defined hypoechoic lesion measuring $5 \times 2.5 \mathrm{~cm}$ with thin echogenic strands in right parotid gland.

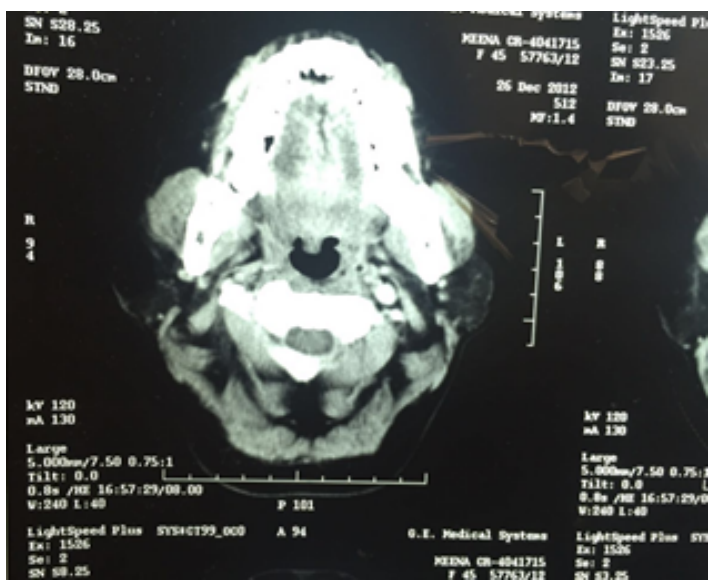

Figure 2: CT scan showing low attenuation homogeneous mass with sharp margins on right side with no underlying anchancement. 


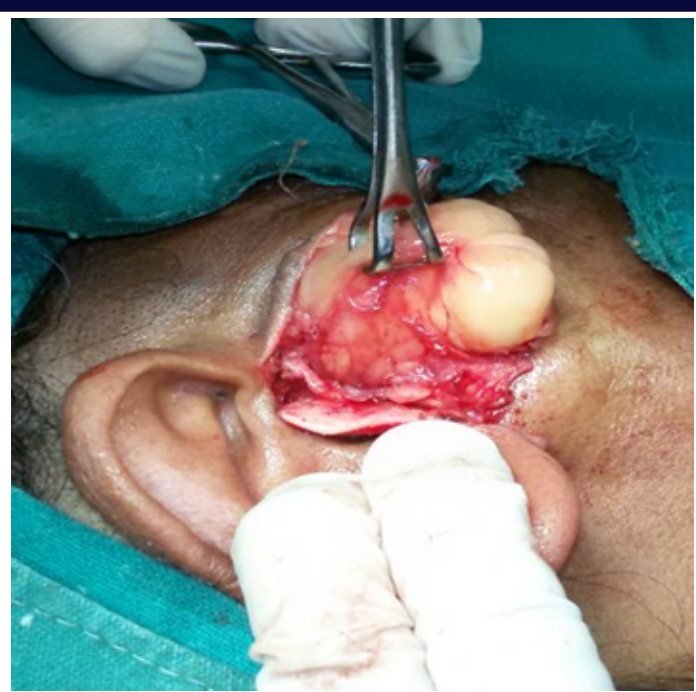

FIGURE 3: Surgical approach: Lipoma excision with facial nerve preservation, under general anesthesia, using a Modified Blair's incision.

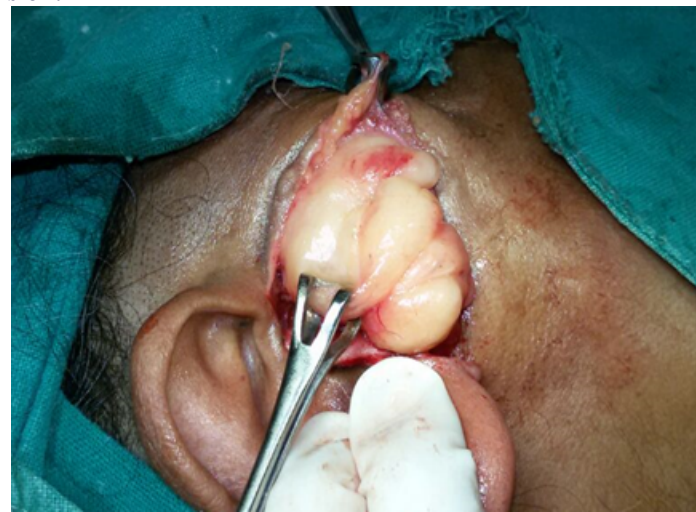

FIGURE 4: Surgical approach: lipomatous lobulated mass being holded with forceps.

\section{DISCUSSION:}

Lipoma is a most common benign tumour arising from mesenchymal tissue $[10,11]$. It constitutes five percent of all benign tumour of body and can be found anywhere in the body [12]. Lipoma in head and neck region are uncommon $[13,14]$. Thirteen percent of lipomas are seen in head and neck region [15]. Anterior neck is an uncommon location forhead and neck lipoma. Histopathologically lipoma is composed of matureadipose tissue surrounded by fibrous capsule [16]. Lipoma is seen in all age group though mostly seen in fifth and sixth decade [17]. Clinically, lipoma presents as painless, mobile, non fluctuant swelling having rubbery consistency. Most of the patients are asymptomatic. Patient with neck lipoma extending to mediastinum may present with complaint of dyspnoea. Ultrasonography acts as the initial imaging modality in diagnosis of head and neck lipoma [12]. Sonographic appearance of head and neck lipomas is characteristic [18,19]. In most cases, they are well defined, elliptical masses parallel to the skin surface and hyper echoic relative to the adjacent muscle. They typically have linear echoes at right angle to ultrasound beam and display no distal enhancement or attenuation [20].Computed tomography is modality of choice to confirm lipoma. Lipomas appear as homogenous low density areas with a CT value of 60 to $120 \mathrm{HU}$ with no contrast enhancement [21].Few septations can be seen within lipoma in CT scan in some cases. Fine needle aspiration cytology or CT is indicated if the diagnosis is doubtful with the clinical impression or if the entire extent or outline of the lipoma is not delineated on the USG (18).On CT scans capsule of lipoma is barely visible or adjacent mass effect may be only clue to its presence [22].

In the parotid gland and the periparotid area, at least 40 cases of lipomatous lesions have been reported [23-29], of which 57\% were intraparotid and $43 \%$ arise in the region around this gland [24]. About $90 \%$ of the cases were ordinary lipomas and the rest were examples of diffuse fatty infiltration or lipomatosis of the parotid gland [26]. The discrete lipomas have a benign clinical presentation and are mostoften confused clinically with Warthin's tumors or pleomorphic adenomas. The lesions vary in size from 1 to $8 \mathrm{~cm}$, are more common in females by a 10:1 ratio, and are not associated with lipomas elsewhere in the body [25]. Complete excision is curative. The differential diagnosis is again limited by the unique low attenuation of the lipoma. Branchial cleft cysts, cystic Warthin's tumors, and abscesses are conceivably in the differential diagnosis, but can be distinguished by the higher central attenuation, the presence of a rim, and associated clinical findings.

In our case lipoma was found superficial to parotid gland without any apparent involvement of parotid gland and other surrounding tissues. Peri parotid lipomas may not be clinically distinguishable from parotid lesions. However, in most cases, CT can easily resolve the true origin of the process.

\section{REFERENCES}

1. Nielsen GP, Mandahl N. Lipoma. In: Fletcher CDM, Unni K, Mertens F, eds. World Health Organization Classification of Tumours. Pathology and Genetics. Tumours of Soft Tissue and Bone. Lyon: IARC Press; 2002. p. 20-2

2. Weiss SW, Goldblum JR. Enzinger \& Weiss Soft tissue tumors. 4th ed. St Louis: Mosby; 2001.p429.

3. Debnath SC, Saikia A. Lipoma of the parotid gland extending from the superficial to the deep lobe: a rarity. Br J Oral Maxillofac Surg. 2010;48(3):203-4

4. Kim DS, Kwon H, You G, Jung SN. Surgical treatment of a giant lipoma in the parotid gland. J Craniofac Surg. 2009;20(5):1601-2.

5. Hohlweg-Majert B, Metzger MC, Dueker J, Schupp W, Schulze D. Salivary gland lipomas: ultrasonographic and magnetic resonance imaging. J Craniofac Surg. 2007;18(6): 1464-6.

6. Batsakis JG. Tumors of the major salivary glands. In: Batsakis JG. Tumors of the head and neck. Clinical and pathological considerations. Baltimore: Williams \& Wilkins; 1979.p. 9 .

7. Barnes L. Surgical pathology of the head and neck. 2nd ed. New York: Marcel Dekker Inc.; 2001.p. $915-24$

8. Das Gupta TK. Tumors and tumor-like conditions of the adipose tissue. In: Ravitch MM. Current Problems in Surgery. Chicago: Year Book Medical: 1970. p. 1-60

9. Vindenes H. Lipomas of the oral cavity. Int J Oral Surg. 1978;7:162-166.

10. Kransdorf MJ; Benign soft tissue tumors in a large referral population: distribution of specific diagnoses by age, sex, and location. AJR Am JRoentgenol 1995; 164:395-402.

1. El-Monem MH, Gaafar AH, Magdy EA; Lipomas of the head and neck: presentation variability and diagnostic workup. J Laryngol Otol 2006; 120:47-55.

12. Enzinger FM, Weiss SW; Benign lipomatous tumors. In: Enzinger FM, Weiss SW,eds. Soft Tissue Tumors. 2nd edn. St Louis: Mosby; 1988; 301-45.

13. Som PM, Scherl MP, Rao VM, Biller HF; Rare presentations of ordinary lipomas of the head and neck: a review. AJNR Am J Neuroradiol 1986; 7:657-664.

14. Barnes L, Ferlito A; Soft tissue neoplasms. In: Ferlito A, ed. Neoplasms of the Larynx. 1st edn. London: Churchill-Livingstone; 1993;:265-304.

15. Barnes L; Tumors and tumor-like lesions of the head and neck. In: Barnes L, ed. Surgical Pathology of the Head and Neck. New York: Marcel Decker Inc; 1985; 747-758.

16. Kim YH, Reiner L; Ultra structure of lipoma. Cancer 1982; 50:102-106.

17. Salam G; Lipom

18. Ahuj AT, Kin AD, Kew J, King W, Metew iC; appearance. AJNR Am J Neuroradiol 1998; 19:505-508.

19. Gritzman N, Schratter M, Traxler M; Sonography and computed tomography in deep cervical lipomas and lipomatosis of the neck. J Ultrasound Med 1988; 7:451-456.

20. Ahuja AT, King AD, King W; Thyroglossal duct cysts: sonographic appearances in adults. AJNR 1999(20):579-582.

21. Dooms GC, Hricak H, Sollitto RA; Lipomatous tumours and tumours with fatty components: MR imaging potential and comparisons between MR and CT results. Radiology $1985 ; 157: 479-83$

22. Weissman JL; Non nodal masses of the neck. In: Som PM, Curtin HD, eds. Head an Neck Imaging. 3rd ed. St Louis, MO: Mosby Year Book; 1996:794-822.

23. EnzingerFM, Weiss SW; Soft tissue tumors St. Louis: Mosby 1983:199-241

24. Janecka IP, Conley J, Perzin KH, Pitman G; Lipomas presenting as parotid tumors Laryngoscope 1977;87:1007-1010

25. WaltsAE, Perzik SL; Lipomatous lesions of the parotid area. Arch Otolaryngol 1976;102:230-232

26. Godwin JT, Dew JH; Fatty infiltration of parotid glands: report of a case. Arch Surg 1958;76:525-526

27. Johansen J, Berdal P; lipomatosis of the parotid gland. Acta Otolaryngol (Stockh) 1970;263: $167-169$

28. Som PM, Sanders DE; The salivary glands in head and neck imaging excluding the brain.Bergeron RT, Osborn AG, Som PM, eds. St. Louis: Mosby, 1984:186-234

29. Adams G, Goycoolea MV, Foster C, Dehner L, Anderson RD; Parotid lipomatosis in a 2 month old child. Otolaryngol Head Neck Surg1981; 89:402-405. 